\title{
Endosperm-specific expression of human acid beta-glucosidase in a waxy rice
}

\author{
Tamara Patti ${ }^{1}$, Bruno Bembi ${ }^{1,2}$, Piero Cristin ${ }^{1}$, Flavia Mazzarol ${ }^{1}$, Erika Secco ${ }^{1}$, Carla Pappalardo ${ }^{3}$, Rita Musetti ${ }^{3}$,
} Maurizio Martinuzzi ${ }^{3}$, Serena Versolatto ${ }^{3}$, Roberta Cariati ${ }^{2}$, Andrea Dardis ${ }^{2}$ and Stefano Marchetti ${ }^{1,3^{*}}$

\begin{abstract}
Background: The deficiency of human acid beta-glucosidase (hGCase) causes Gaucher disease, a rare genetically-inherited disorder currently treated by enzyme replacement therapy using recombinant CHO-derived GCase. In an attempt to provide an alternative and more efficient production system, a chimeric cDNA coding for hGCase operatively linked to the signal peptide of rice glutelin 4 (GluB4) was put under the control of the GluB4 endosperm-specific promoter and inserted into the genome of a waxy rice.

Results: Molecular, immunological and biochemical analyses showed that recombinant hGCase, targeted to the protein storage vacuoles of rice endosperm cells, is equivalent to the native protein and has a glycosylation pattern compatible with direct therapeutic use. Compared to a previous study carried out on transgenic tobacco seeds, enzyme contents per unit of biomass were drastically increased; in addition, differently from what observed in tobacco, rice seed viability was unaffected by hGCase even at the highest production level. Transgenic seed polishing combined with a pretreatment of seed flour greatly facilitated hGCase extraction and purification with an industrially-scalable procedure.
\end{abstract}

Conclusions: This study opens up the possibility to efficiently produce in the rice seed pharmaceutical compounds which are available in limited amounts or completely excluded from clinical practice due to the inadequacy of their production systems.

Keywords: Human acid beta-glucosidase, Gaucher disease, Transgenic rice, Pharmaceutical proteins, Endosperm-specific expression, Molecular farming

\section{Background}

Human acid beta-glucosidase (hGCase; EC 3.2.1.45) catalyzes the hydrolytic cleavage of glucose from glucosylceramide in lysosomes (Brady et al. 1965). It is a homomeric glycoprotein of 497 amino acids with a molecular mass ranging from 60 to $68 \mathrm{kDa}$, containing five putative $\mathrm{N}$-glycosylation sites, four of which are normally occupied (Berg-Fussman et al. 1993; Brumshtein et al. 2006). The quantitative/qualitative deficiency of hGCase leads to an accumulation of glucosylceramides in lysosomes and causes the Gaucher disease (GD), one of the most frequent human sphingolipidosis. Fatty material can collect in the spleen, liver, kidneys, lungs, brain

\footnotetext{
* Correspondence: stefano.marchetti@uniud.it

${ }^{1}$ Transactiva Srl, Via J. Linussio 51, 33100 Udine, Italy

${ }^{3}$ Department of Agriculture and Environmental Sciences, University of Udine, Via delle Scienze 206, 33100 Udine, Italy

Full list of author information is available at the end of the article
}

and bone marrow. Main clinical symptoms may include hepatosplenomegaly, anaemia, thrombocytopenia and skeletal deterioration (Beutler and Grabowsky 2001). GD has a pan-ethnic diffusion but its frequency is particularly high $(1: 640$ to $1: 10,000)$ in the Ashkenazi Jewish population (Beutler and Grabowsky 2001; Cox and Schofield 1997), whereas in the non-Jewish population data are varying from 1:57,000 to 1:200,000 (Cox and Schofield 1997; Meikle et al. 1999).

GD is currently treated by enzyme replacement therapy (ERT) using mainly a recombinant processed form of human acid beta-glucosidase (commercial imiglucerase) obtained from cultured $\mathrm{CHO}$ cells. Regular infusions of the missing enzyme were found effective in reducing the visceral and bone marrow storage of glucosylceramides, decreasing spleen and liver volumes, normalizing/stabilizing hematochemical parameters $(\mathrm{Hb}$, platelets, hepatic enzymes, chitotriosidase) and improving the quality of life 
of GD patients (Grabowski et al. 1995; Damiano et al. 1998). However, the current production system based on $\mathrm{CHO}$ is economically very expensive and limits the drug amounts present on the market, seriously hindering the maintenance and the diffusion of therapeutic regimes.

Moreover, an acute shortage of commercial imiglucerase has recently occurred as a result of viral contamination of the production facility, forcing all countries to reassess their stocks and to establish new priorities of drug supply to patients (Hollak et al. 2009).

Although an additional two enzymatic forms were approved for early access clinical programs, i.e. velaglucerase alpha (from cultured human fibroblasts; Aerts et al. 2010) and taliglucerase alpha (from cultured carrot cells; Shaaltiel et al. 2007, Aviezer et al. 2009), the drug shortage has underlined the necessity to find a valid alternative production system to guarantee sufficient drug supply to patients not only for Gaucher disease, but also for other disorders and diseases curable with lifelong therapies.

Molecular farming, i.e. the production of valuable recombinant proteins in plants (Schillberg et al. 2003), can represent a good solution to this need, because plants have several advantages over traditional platforms for recombinant pharmaceutical protein production. Plants are inexpensive, they are highly scalable, they offer high product quality and they do not support human pathogens. Crops producing pharmaceutical molecules can be established with minimal upfront investment in infrastructures, unlike the major fermentation-based platforms (Fischer et al. 2012).

Concerning Gaucher disease, in a previous study, a procedure for production and immuno-purification of human acid beta-glucosidase in tobacco seeds was developed (Reggi et al. 2005). The plant-derived enzyme was found stable, active and taken up by human target cells; nevertheless, it was also found that the best transgenic lines could not be maintained through sexual reproduction due to seed non viability; this fact combined with the tiny dimensions and the high lipid content of tobacco seed had a negative impact on industrial scalability.

The present paper describes a novel technological platform for the large-scale production of recombinant human GCase (rhGCase) in the endosperm of Oryza sativa $\mathrm{L}$. In the new system, seed germination is not impaired by the recombinant enzyme, protein extraction and purification can be easily performed with resins available in bulk amounts and the product quality appears largely suitable for therapeutic purposes.

\section{Results}

\section{Rice transformation and molecular analyses on} primary transformants

Compared to other japonica varieties, the waxy rice CR $\mathrm{W} 3$ is less responsive in vitro, therefore preliminary experiments were done to select the best conditions for embryogenic callus formation and plant regeneration. Agrobacterium-mediated transformation was efficient only when scutellum-derived calli were less than $1 \mathrm{~mm}$ in diameter, non-friable, whitish and roundly shaped; moreover, such calli had to be used within 10 days after isolation and selection. Regenerated plants were analysed by PCR to verify the presence of both $h G$ Case and selection marker genes (Figure 1). A total of 67 plants were found positive and used for further analyses. A sample of 16 randomly-chosen transformants was used to estimate the transgene copy number by real-time qPCR. In these experiments, the endogenous reference was the sucrose phosphate synthase $(S P S)$ gene, which is present in a single copy in the haploid rice genome. Titration curves were obtained by regressing threshold cycles on known dilutions of SPS and hGCase genes; correlation coefficients between the two variables ranged from 0.985 to 0.993 . PCR efficiencies were above 0.90 . In the sample of primary transformants, transgene copy number was in most cases $\leq 3$ and never higher than 4 .

\section{Western blot analyses on seed protein extracts}

As formerly described, the human GCase gene was linked to an endosperm-specific rice glutelin (GluB4) promoter, enhanced by the substitution of its native leader region with the synthetic LLTCK 5' UTR (De Amicis et al. 2007). To confirm the endosperm expression of the GluB4 promoter, seed protein extracts were analyzed by Western blotting using the anti-GCase serum raised in rabbit after injection of the GCaseanalogue imiglucerase. These analyses demonstrated that rhGCase is accumulated in the developing seed. No cross-reacting proteins were ever identified in seed protein extracts of untransformed control. In all transgenic samples, the antibody revealed a single protein band, having an apparent molecular weight of $60 \mathrm{kDa}$, that is very similar to commercial imiglucerase (Figure 2). Since the molecular mass of the unglycosylated protein is $55.6 \mathrm{kDa}$, this result indicated that rhGCase produced in the rice endosperm is glycosylated with low molecular weight $\mathrm{N}$-glycans.

The Western blot signal intensity differed among lines; since in a previous study the band intensity was found correlated with rhGCase content (Reggi et al. 2005), Western blotting was used to select the best primary transformants, until a consistent ELISA was developed. The protein extracts of 18 transformants repeatedly gave better results; this superiority was confirmed in Western blot analyses carried out using different sample dilutions. Best transformants were grown to produce a $\mathrm{T}_{2}$ generation for further quantitative analyses, whereas the seed of the remaining lines was bulked and used to develop the GCase purification procedure. 


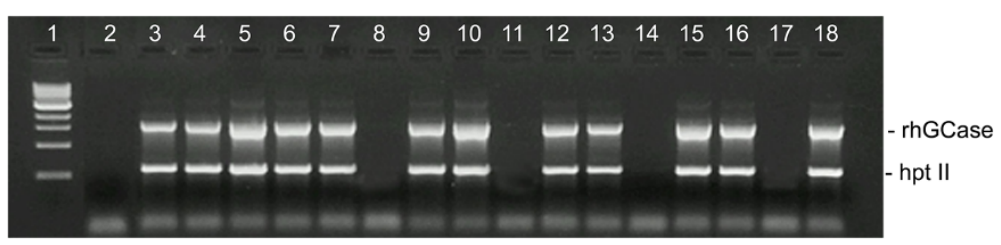

Figure 1 Duplex-PCR products obtained using primers specific for hGCase and $\boldsymbol{h}$ pt-Il (hygromycin resistance) genes. Lane 1: $1 \mathrm{~kb}$ ladder (NEB); 2: negative control (untransformed CR W3); 3-18: tested plants.

\section{Subcellular localization of recombinant GCase}

The glutelin 4 signal peptide was used with the expectation that rhGCase would be targeted to the protein storage vacuoles (PSVs) within the endosperm cells. To precisely determine the site of rhGCase accumulation and storage, transformed and untransformed seeds were repeatedly examined at the transmission electron microscope following immunogold labeling. Since this immunocytochemical technique does not preserve the ultrastructural morphology of the tissues, the main cellular ultrastructures of rice seed endosperm were preliminary identified in osmium-treated samples (Figure 3A). No signal was ever found in untransformed control seed; differently, in transgenic seed the presence of the recombinant enzyme was revealed exactly where it was planned, i.e. within protein storage vacuoles (PSVs) of the seed endosperm (Figure 3C); interestingly, no immunogold labeling was obtained in the protein bodies.

\section{Tissue-specific expression analyses}

Protein samples extracted from different tissues/organs showed the typical electrophoretic pattern; no difference was noted between the transgenic line and the CR W3 variety providing the genetic background (Figure 4B and 4D).

Western blot analyses indicated the endospermspecific expression of rhGCase (Figure 4A). No cross-

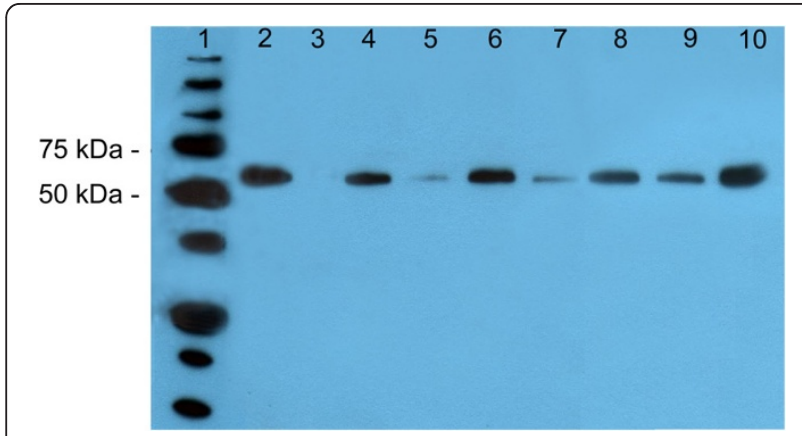

Figure 2 Western blot analysis of crude seed protein extracts. Lane 1: Precision Plus Protein standard (BioRad); 2: positive control (100 ng imiglucerase); 3: negative control (protein extract from untransformed CR W3 seed); 4-10: tested plants. reacting protein appeared in the negative control CR W3 (Figure 4C).

Results obtained with DAS-ELISA were consistent in showing the endosperm-specific expression of the rhGCase gene (Figure 5). Some background noise was evidenced for root and embryo protein extracts but the overall clearness of the data was not hampered in any respect.

\section{rhGCase extraction and purification}

On the basis of the endosperm-specific localization of rhGCase, a first trial took into consideration the possible advantage of seed polishing for the partial removal of protein contaminants. Transgenic white rice was milled and analysed in parallel with the polishing waste. From the combination of the results obtained in SDS-PAGE and Western blotting, it appeared that, differently from the large part of contaminants, only a minimal quantity of rhGCase is removed during processing (Figure 6). Subsequent experiments were designed to determine the conditions for rhGCase extraction from polished seed flour. Figure 6 shows the results obtained in 5 and 2 serial extractions carried out on the polished seed flour and the polishing waste, respectively. It is evident from the figure that most rhGCase is recovered from flour with the first three extractions and that in the fifth extract the enzyme is hardly detectable. Percent enzyme recovery as estimated by ELISA in the first, second and third extraction was $64.7,22.9$ and $7.2 \%$, respectively.

DAS-ELISA was also used to determine the rhGCase content in polished rice flour derived from a bulk of unselected seeds harvested from the best primary transformants. The overall estimated yield was $143 \mathrm{mg}$ of rhGCase per $\mathrm{kg}$ of flour.

With respect to rhGCase purification, the high ionic strength of the extract superimposed the choice of HIC (Hydrophobic Interaction Chromatography) for GCase capturing and IEC (Ion Exchange Chromatography) for intermediate purification. All chromatographic fractions were analysed by ELISA, SDS-PAGE and Western blotting. Under the conditions reported in this paper, both chromatographies were quite efficient in enzyme recovery as well as in the exclusion/removal of contaminants. In the final polishing step with Hiprep 16/60 Sephacryl 

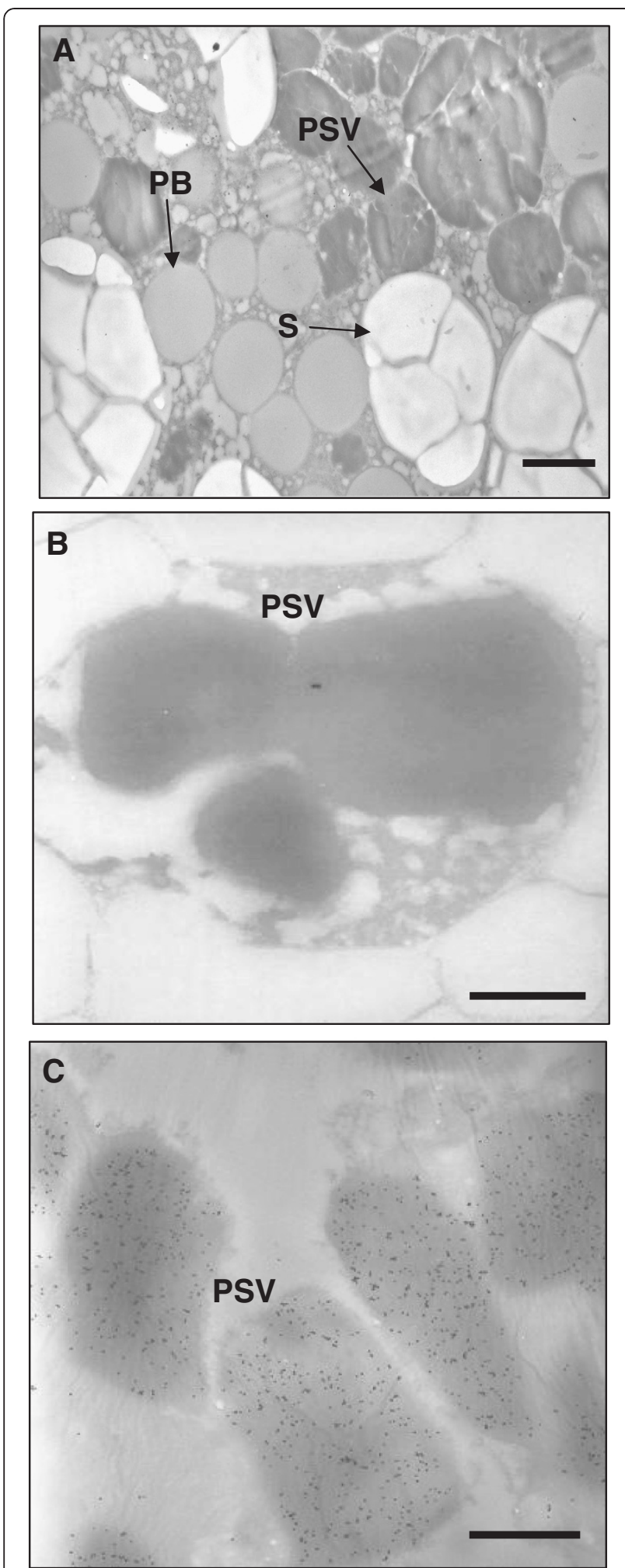

Figure 3 Electron and immunoelectron microscopy on rice endosperm sections. Micrograph of unlabelled osmium-treated sample (A), untransformed control (B) and transformed rhGCase seed (C). PSV: protein storage vacuole; PB: protein body; S: starch granule. Bars $=3 \mu \mathrm{m}$ in $(\mathbf{A}), 1 \mu \mathrm{m}$ in $(\mathbf{B})$ and $(\mathbf{C})$.
S-100 column, the enzyme was collected in a single peak after a retention volume equal to $56.4 \mathrm{~mL}$, which was very close to that of commercial imiglucerase, equal to $55.9 \mathrm{~mL}$. Total removal of contaminants was confirmed in SDS-PAGE (Figure 7) and ELISA analyses based on titration curves made with commercial therapeutic-grade imiglucerase. Data regarding the efficiency of each chromatographic step are shown in Table 1.

\section{Seed viability}

Percent viability was excellent (99-100\%) in both transformed seed samples and untransformed control. No dormancy was recorded in any seed lot, consistently with previous observations on germination behaviour of the CR W3 variety. As shown in Figure 8A, seed viability and the time course of germination were similar for untransformed control and two transformants with a sharply different rhGCase content (63.5 and $215 \mathrm{mg}$ per $\mathrm{kg}$ of flour). In contrast, best tobacco transformants produced according to Reggi et al. (2005) had a seed germination capacity equal to zero (Figure $8 \mathrm{~B}$ ). It is worthy of note that the best tobacco plant had $32 \mathrm{mg}$ rhGCase per $\mathrm{kg}$ of seed flour, i.e. approximately one half of the enzyme content recorded in the rice lower producer. This evidence demonstrates that rhGCase accumulation and seed germination can be effectively uncoupled through endosperm-specific expression in a monocot system.

\section{Peptide mass fingerprinting and $\mathrm{N}$-terminal sequencing}

MALDI-TOF analysis carried out on a purified rhGCase sample digested with trypsin confirmed its equivalence with human GCase [GenBank: J03059]. The results achieved with the Mascot proteomic software (www. expasy.org/tools) were clear-cut: rhGCase identification was obtained with a score of $10^{-32}$ and the percent protein coverage was equal to $53 \%$ (Figure 9). It is interesting to note that both the amino- and the carboxyterminus of the protein were included in the list of recognized peptides and that they resulted fully equivalent with the corresponding sequences of human GCase. Differently, the peptides containing the first, second and fourth $\mathrm{N}$-glycosylation site were not detected through the Mascot analysis, because in all likelihood these sites were occupied by oligosaccharidic chains. More details on glycan structure are reported hereinafter.

The identity of the rhGCase N-terminal sequence was also determined through conventional Edman analysis. The resulting data confirmed that the first 9 amino acids of rhGCase correspond exactly to the first tract of the human mature polypeptide. Hence, it was demonstrated again that the signal peptide of glutelin 4 is well recognized and properly removed from the precursor protein during traslocation in the ER. 


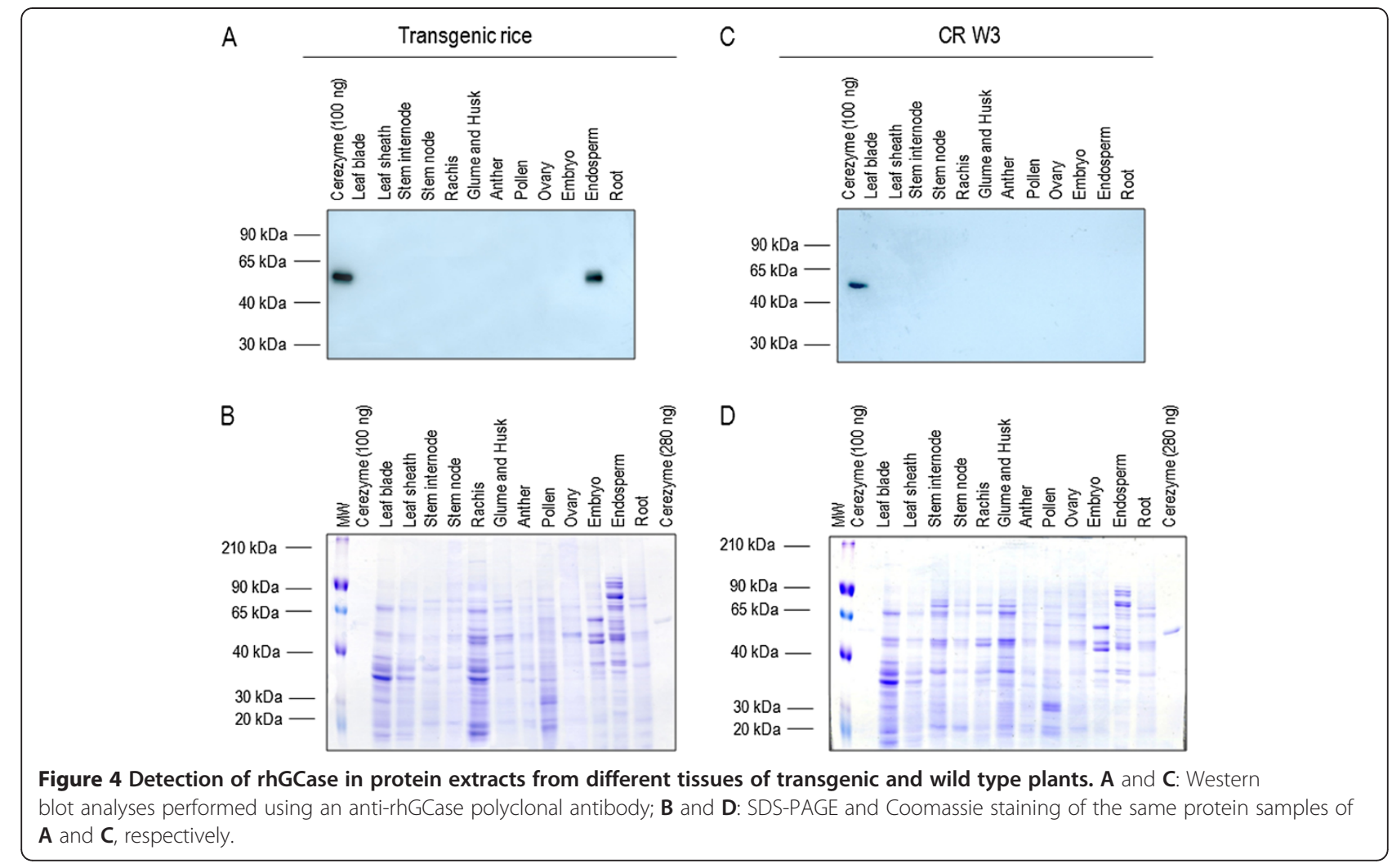

\section{Glycan structure analyses}

$\mathrm{N}$-glycosylation was partially characterized by digesting a purified rhGCase sample with PNGase F. MALDITOF data processing of the oligosaccharidic chains suggested the presence of 12 glycan forms. Figure 10 reports the glycan structures identified in rhGCase with the Glycomode software tool (www.expasy.org/tools). All oligosaccharide chains shared the typical paucimannosidic structure of N-linked glycans of PSV proteins (Lerouge et al. 1998). In all cases but one, they were found to have at least one chain-terminating mannose residue needed for GCase uptake by human cells. Even though MALDITOF analysis does not allow a precise quantification of the different forms, mass spectra showed that Man3GlcNAc2

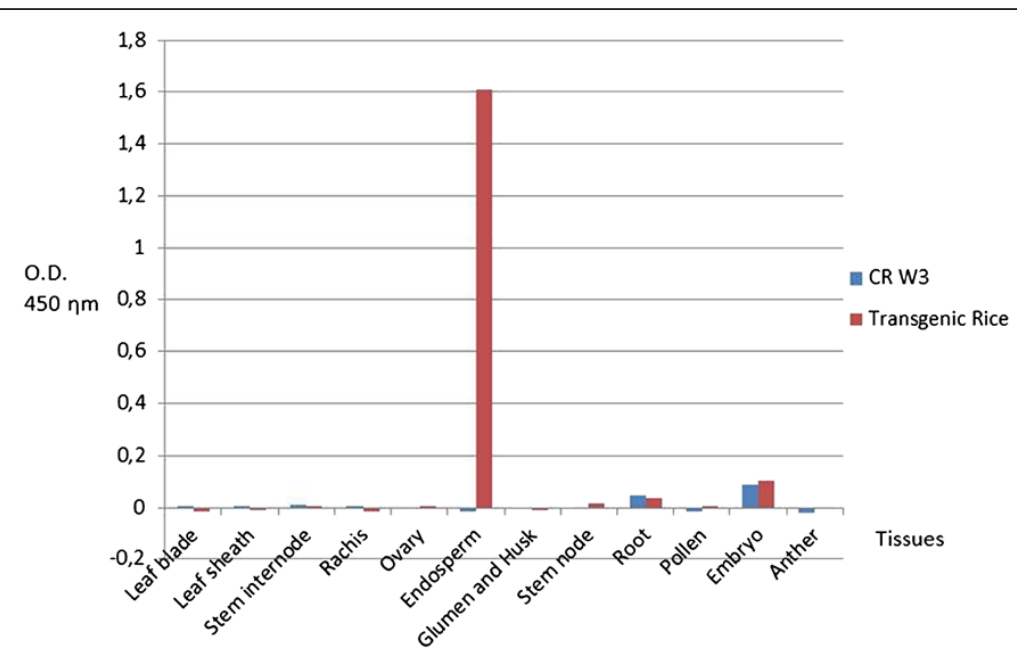

Figure 5 Results of DAS-ELISA analyses carried out on protein samples obtained from different tissues of transgenic and wild type plants. O.D.: optical density. 


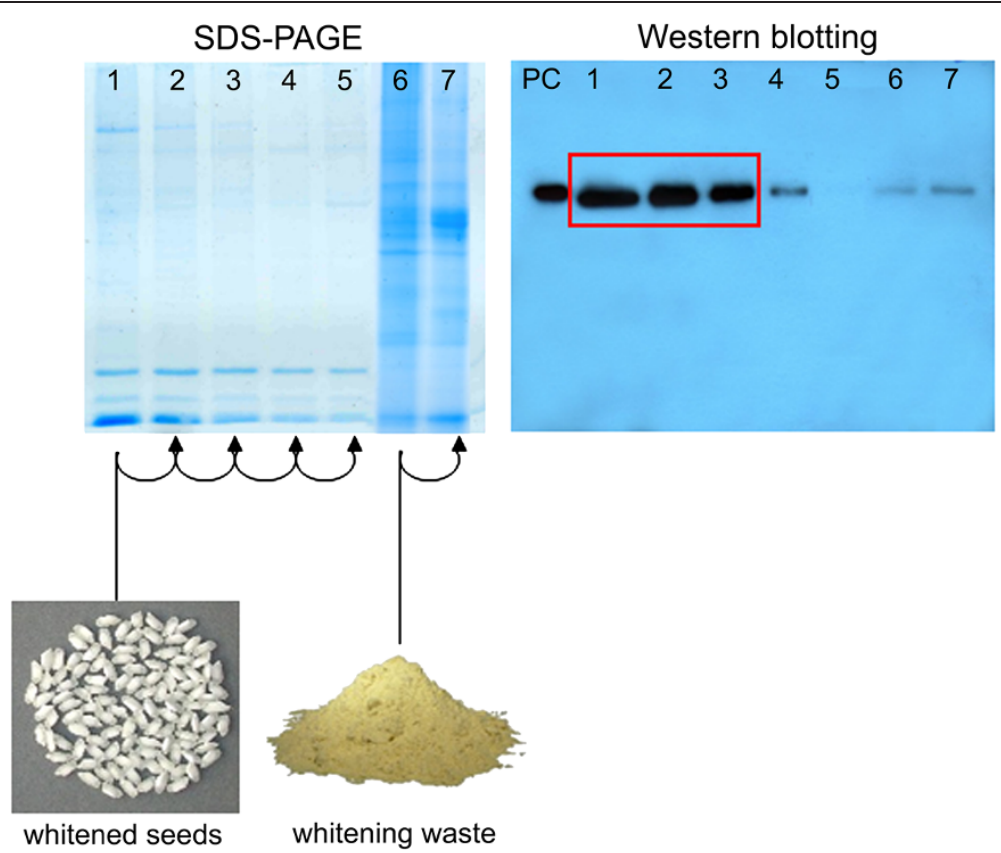

Figure 6 SDS-PAGE and Western blot analyses of crude protein samples obtained during extraction trials. Lanes 1-5: serial extractions from polished seed; lanes 6-7: serial extractions from polishing waste. PC (positive control): 100 ng imiglucerase.

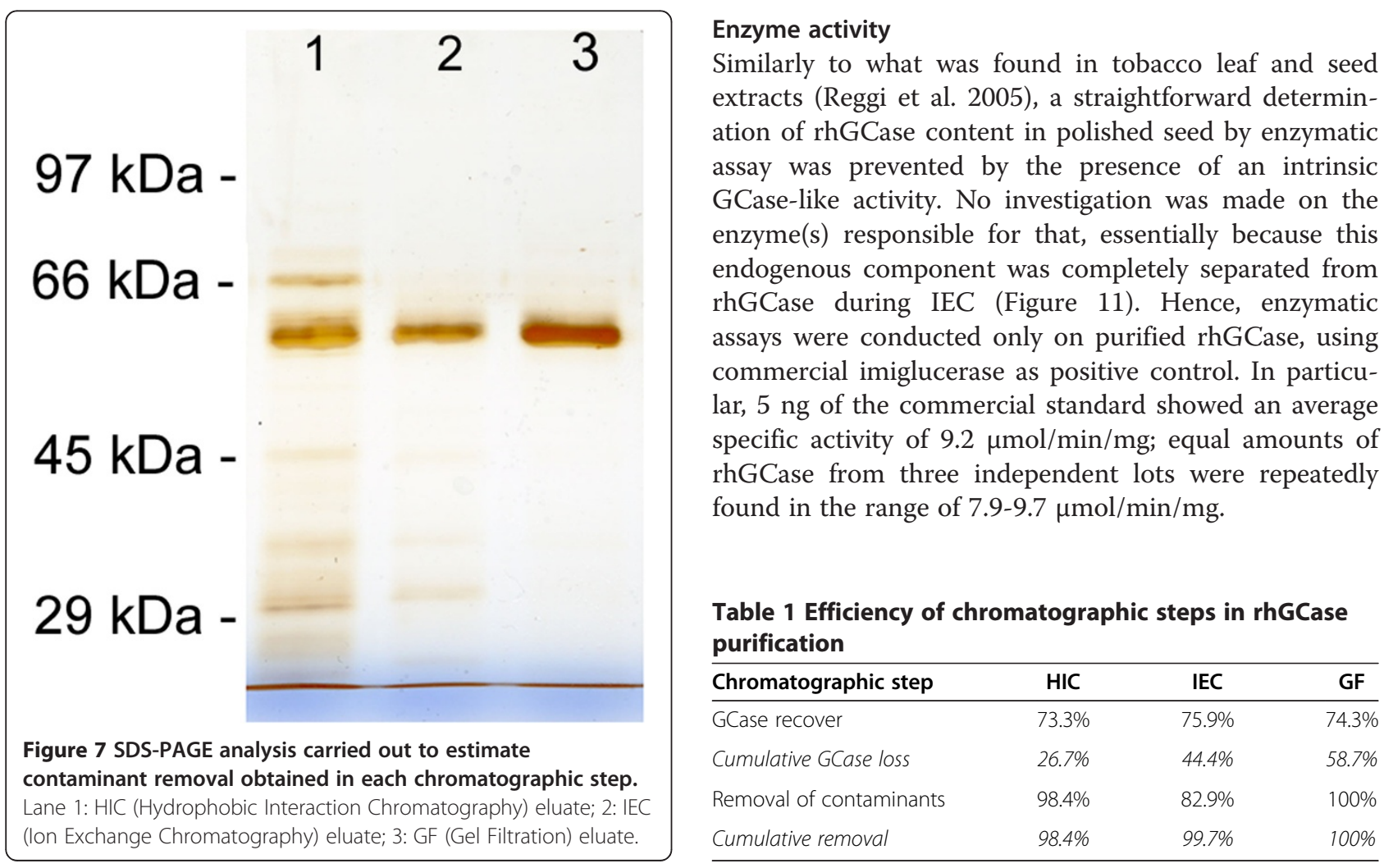



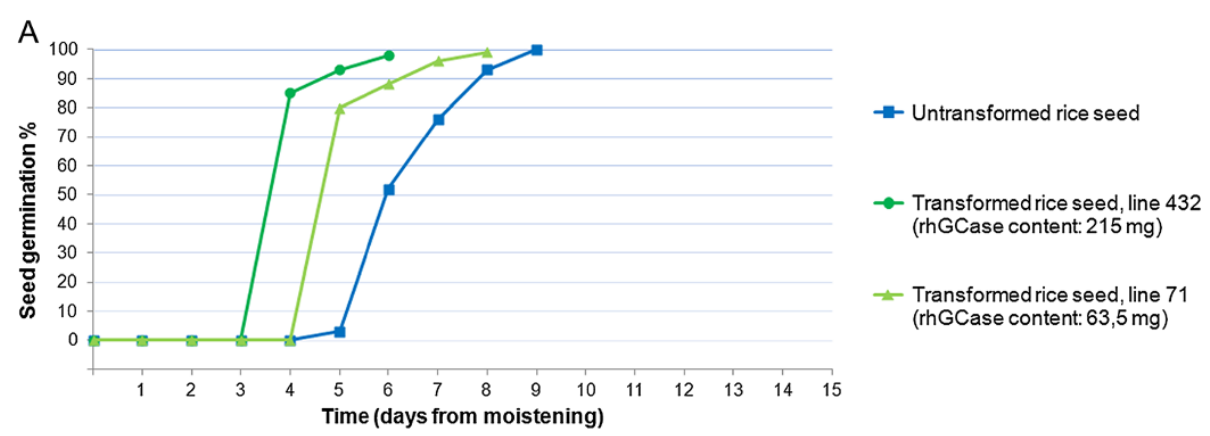

B

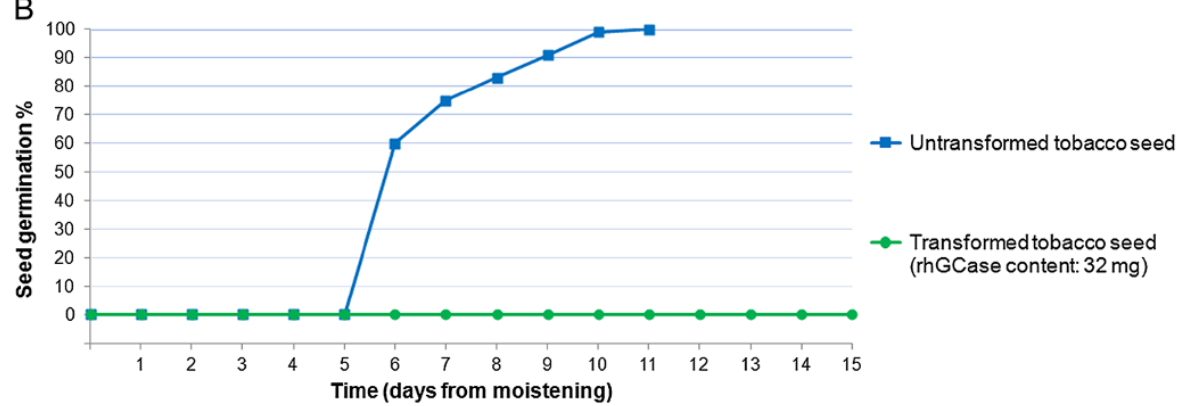

Figure 8 Results of seed viability tests in rice and tobacco. A: untransformed and transformed rice seeds; B: untransformed and transformed tobacco seeds.
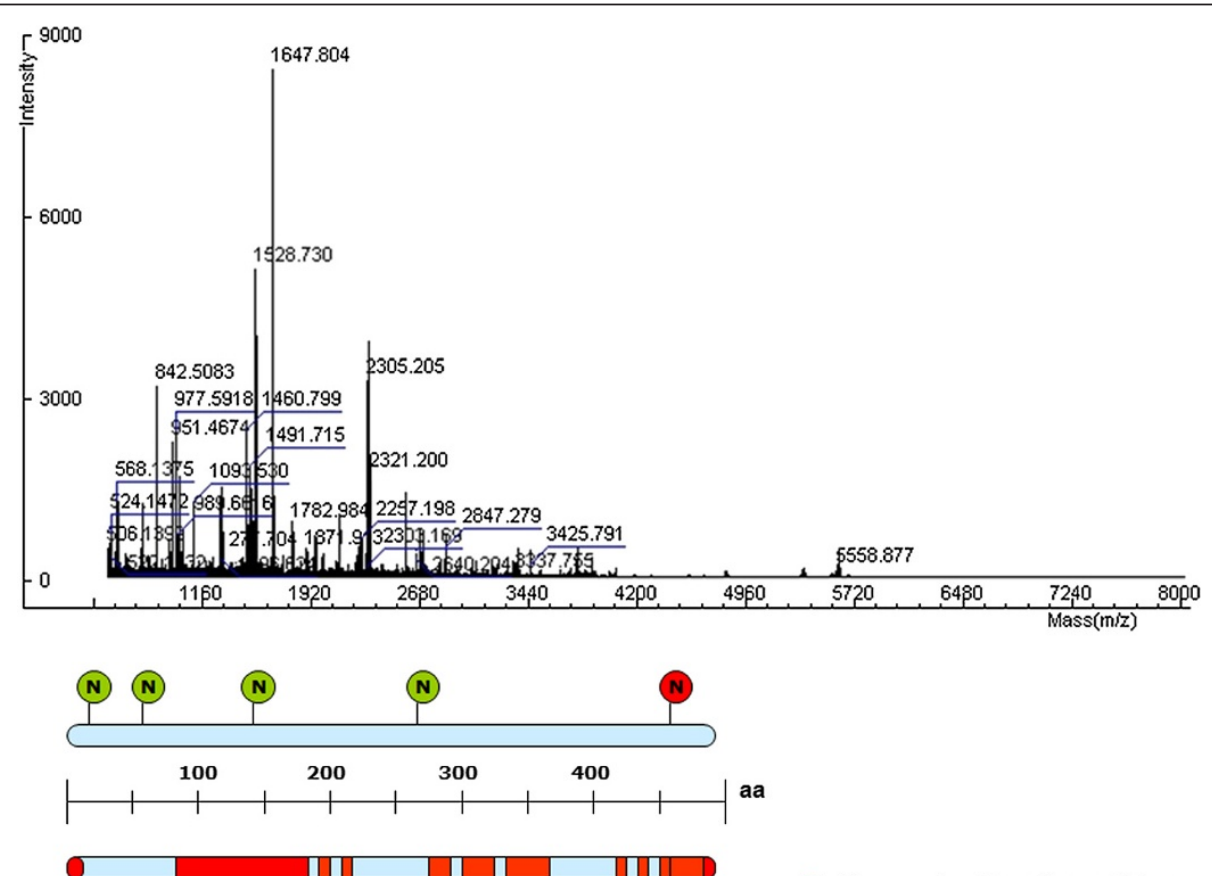

Figure 9 MALDI-TOF analysis of a rhGCase sample purified by HIC and IEC chromatography. Red bars indicate rhGCase tryptic peptides assigned to human GCase regions. The position of the five putative N-glycosylation sites is shown by circles; all sites except the last one, which never harbours glycans (Berg-Fussman et al. 1993), are normally occupied by oligosaccharidic chains. 


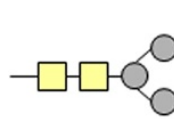

892

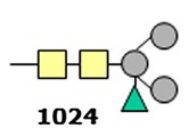

1024

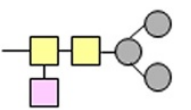

1038
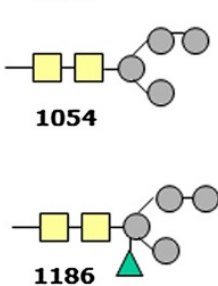

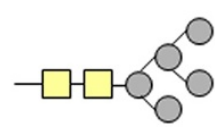

1216
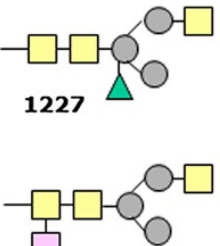

1241
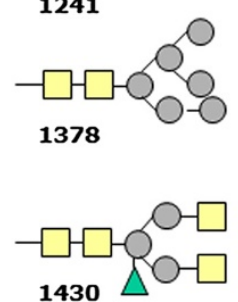

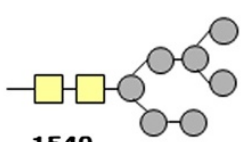

1540

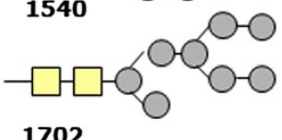

1702

\section{$\square \mathrm{N}$-acetylglucosamine}

\section{$\triangle$ xylose \\ $\square$ fucose}

Figure $10 \mathrm{~N}$-glycan structures and related molecular masses predicted in rice-derived rhGCase by Glycomode analysis.

\section{Discussion}

Among different methods described for the production of recombinant proteins in plants, those involving the seed are particularly attractive because seeds are natural organs devoted to the production and accumulation of storage proteins in a small volume and in a stable biochemical environment. In particular, neo-synthesized proteins are targeted to subcellular storage compartments such as protein bodies and protein storage vacuoles, where they can be preserved for a long time due to a low water content and the presence of proteinase inhibitors (Takaiwa et al. 2007).
In former experiments (Reggi et al. 2005), it was demonstrated that recombinant human GCase can be stored in a stable and active form in tobacco seed. However, in the best primary transformants, seed viability appeared totally impaired and all attempts to overcome the problem were unsuccessful (Reggi et al. 2005). This evidence, together with a high oil content and tiny dimension of tobacco seed, prompted us to consider rice as an alternative host-species.

In seed-specific expression studies carried out in tobacco, recombinant proteins are typically accumulated in the cotyledon parenchymatic tissue, hence they can
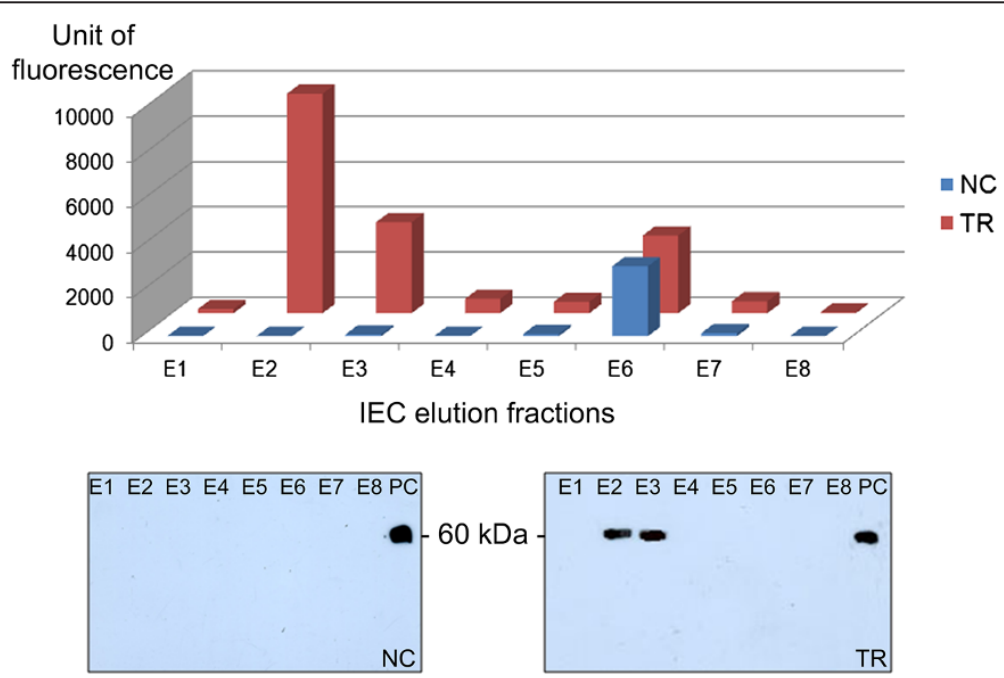

Figure 11 Fluorescence recorded in comparative 4-MUG catalytic assays performed on 8 IEC elution fractions. NC (negative control): untransformed CR W3; TR: transformed CR W3 plants; E1-E8: elution fractions; PC (positive control): 100 ng imiglucerase. 
directly interfere with embryo development and seed germination. Differently, in rice there is the opportunity to allocate recombinant proteins in the endosperm, i.e. a tissue separated by the embryo and metabolically inert at maturity. Beside this, rice seeds can be industrially processed to separate the hulls, the germ and the aleuronic layer. The removal of these components, which is relatively inexpensive, greatly favours the extraction and purification of heterologous proteins because both the lipid content and the number of protein contaminants are minimized.

Among other advantages in using rice as bioreactor, there is the availability of some non-food varieties with easily-recognizable genetic markers (Takaiwa et al. 2007). In this work, essentially for biosafety issues, the japonica waxy rice CR W3 was used; CR W3 is a registered variety with round-shaped seed developed by the Rice Research Centre of Ente Nazionale Risi (Milan, Italy) but insofar awaiting commercial exploitation. Due to an almost void amylose content, CR W3 seed can be used for the production of starch and related byproducts, whereas its employment as human food is difficult for the remarkable loss of consistency with boiling.

The endosperm-specific accumulation of rhGCase in CR W3 seed was gained through the use of the rice glutelin 4 promoter (GluB4pro). In a former study carried out with different seed-specific promoters $(\mathrm{Qu}$ and Takaiwa 2004), GluB4pro determined the highest level of GUS expression in transgenic rice. The maximum accumulation of the GUS protein was observed in the inner starchy endosperm, close to the late maturation stage.

In our experiments, GluB4pro showed a similar expression pattern: in fact, rhGCase was detected exclusively in the seed endosperm and not in other vegetative or reproductive tissues; moreover, SDS-PAGE and Western blotting analyses indicated that only negligible amounts of rhGCase are lost with seed polishing, a process that eliminates the germ and the aleuronic/sub-aleuronic layers (Figure 6).

Much interestingly, neither seed viability nor dormancy were affected by rhGCase endosperm-specific expression; in all instances percent viability was excellent (99-100\%) and resembled that of untransformed control. These data clearly demonstrate that the problem of seed viability loss recorded for tobacco plants (Reggi et al. 2005) is non-existent in rice.

It is important to underline that, despite seed protein content is significantly lower in rice compared to tobacco, in rice endosperm rhGCase expression levels were found much greater than those recorded in the best tobacco transformants, perhaps due to more permissive physiological conditions and the triploid nature of the tissue. The achievement of high transgene expression levels is crucial for developing a technological platform for industrial scale-up; beside promoters, several molecular elements must be considered, including 5' UTR and the signal peptide sequence for specific subcellular localization. For the purpose of this study, the GluB4 native leader was replaced with the artificial leader LLTCK (De Amicis et al. 2007) mainly characterized by the combination of a poly(CAA) region with a CT-rich motif. In previous studies, the LLTCK leader determined a 12.5-fold enhancement of uidA expression in tobacco leaf as compared with the native CaMV $35 \mathrm{~S}$ leader sequence (De Amicis et al. 2007). No experimental evidence about the utility of LLTCK in monocot plants has been published so far; it should be noted however that, although not in association between each other, CT- and GA-rich regions occur in the proximity of the transcription start site of many plant genes, particularly in monocots (Chen et al. 1996).

As far as subcellular targeting is concerned, its influence on folding, assembling, post-translational modifications and stability of a protein is widely recognized (Twyman et al. 2003; Doran 2006; Benchabane et al. 2008). In this study, the signal peptide of glutelin 4. (SPGluB4) was used; immunolabelling results demonstrated that this SP determined a rhGCase accumulation in the same storage compartment of GluB4, i.e. the protein storage vacuoles (PSVs) (Takaiwa et al. 1999; Kawakatsu et al. 2008).

Similarly to other PSV-allocated recombinant proteins (Humphrey et al. 2002; Arcalis et al. 2004; Vitale and Pedrazzini 2005), both rhGCase content and activity were maintained unaltered after 12 months of storage (data not shown).

The use of a signal peptide for ER-targeting is an acquainted technology; a more challenging aspect is represented by the prediction of both SP removal and cleavage site. If the SP is not separated from the protein, the precursor-complex can remain anchored to the ER outer membrane (Yan et al. 1997) and in any case it does not assume the correct tertiary structure. On the other hand, if the SP is removed but cleavage does not occur in the exact position, different non-authentic versions of the mature protein may arise. This condition is absolutely detrimental for therapeutic proteins since mutated forms are potentially immunogenic or provided with different pharmacodynamic properties. Some software tools were devised for prediction of the SP cleavage site in different host systems (Emanuelsson et al. 2007). In the present work, both SignalP 3.0 (http://www.cbs.dtu.dk/services/ SignalP) and SIG-PRED (http://bmbpcu36.leeds.ac.uk/ prot_analysis/Signal.html) were preliminary used to determine the probability of proteolytic cleavage of SPGluB4/ GCase complex; in either case, the predicted site corresponded exactly to the boundary between SPGluB4 and mature GCase (MATIAFSRLSIYFCVLLLCHGSMA// ARPCIPKSF...). In fact, $\mathrm{N}$-terminal sequencing revealed that SPGluB4 is well recognized and correctly removed, 
thus originating a mature protein whose amino acid sequence is perfectly identical to the human one.

Another important issue for injectable proteins produced in plants concerns the type and level of N-glycosylation. Glycan analyses performed by MALDI-TOF on oligosaccharide chains of rice-derived GCase revealed that 11 out of 12 predicted glycoforms are mannose-ending, which is an essential pre-requisite for human cell internalization. This represents a further advantage in the clinical use of rice-derived GCase in comparison with $\mathrm{CHO}$ derived molecule. In fact, the latter must be partially deglycosylated in order to expose mannose residues which are specifically recognized by endocytic carbohydrate receptors on macrophages of reticulo-endothelial system. This enzymatic process complicates the purification step and increases production costs (Futerman et al. 2004). Preliminary assays conducted on human target cells demonstrated that the rice seed-derived enzyme is wellrecognized and taken up at levels comparable to those of the commercial imiglucerase (data not shown).

\section{Conclusions}

This paper describes an industrially-scalable method to produce human acid beta-glucosidase in rice endosperm. Likewise, the same procedure can be applied to efficiently produce pharmaceutical compounds which, similarly to rhGCase, are potentially harmful to the plant cell.

The platform overcomes some important difficulties faced in previous work, more specifically:

- it allows a tissue-specific expression and a consistent subcellular localization of human acid beta-glucosidase inside the rice seed;

- it allows the production of a pharmaceutical molecule suitable for therapeutic use;

- it does not affect seed viability thus enabling the maintenance and multiplication of productive lines through sexual reproduction;

- it facilitates both enzyme extraction and purification, improving the overall management of the productive process;

- it is economically more convenient compared to the $\mathrm{CHO}$-technology, thus setting the conditions for a more affordable therapy of Gaucher disease.

Rice-derived rhGCase displays all the molecular characteristics and pharmaceutical prerequisites for ERT of Gaucher disease, being highly equivalent to the native human enzyme.

\section{Methods}

Construction of the plant expression vector pTRSO_GCase This vector was developed from the commercial plasmid pCAMBIA1300 [GenBank: AF234296] by introduction of the GCase cassette into the Eco RI site. The GCase cassette was designed to harbour the rice storage protein glutelin 4 promoter (GluB4pro), the human GCase CDS and the nopaline synthase terminator of Agrobacterium tumefaciens (NOS-ter).

The GluB4pro sequence was PCR-isolated from rice genomic DNA (Oryza sativa ssp. japonica, var. CR W3) with primers designed on the basis of GenBank acc. No. AY427571 (forward 5'- GCATGCGAATTCTACAGGG TTCCTTGCGTG-3'; reverse 5'-TCTAGAAGCTATTT GAGGATGTTATTGGAA-3'). In order to improve rhGCase expression levels, the native 5'-UTR was substituted with the LLTCK leader (De Amicis et al. 2007). RhGCase targeting to the protein storage vacuoles (PSVs) was attempted with the transit peptide of rice glutelin 4 (Uniprot code P14614 [1-24]). Promoter, LLTCK leader and transit peptide sequences were ligated immediately upstream the GCase mature polypeptide CDS [GenBank: M16328, nt 553-2043]; the GCase coding sequence was obtained by RT-PCR from human placental total RNA. The expression cassette was completed by the addition of nos-ter.

After cloning into the final expression vector pTRS0_GCase (Figure 12), all sequences were verified on both strands.

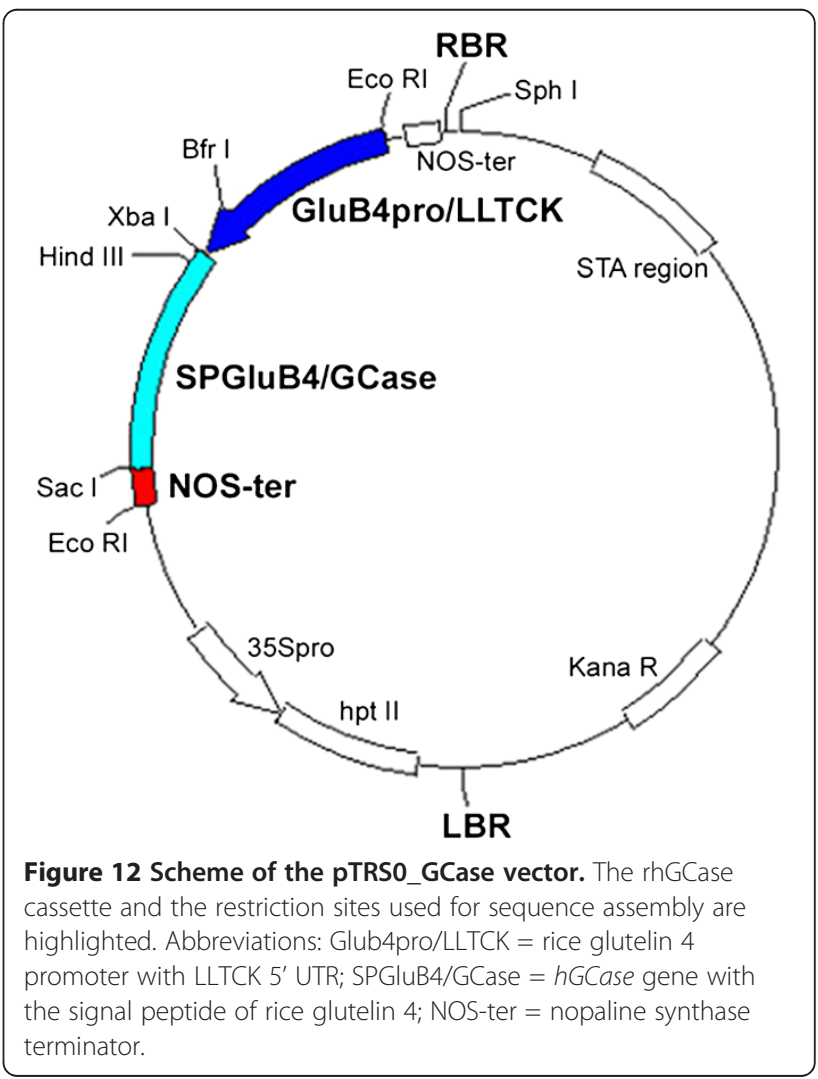




\section{Rice transformation and molecular analyses on primary transformants}

The engineered vector was introduced into Agrobacterium tumefaciens, strain EHA105, by electroporation. Rice transformation was carried out according to Hiei et al. (1994) with minor modifications. Putatively transformed (i.e. hygromycin resistant) plants were potted in peat, hardened in a greenhouse and maintained until seed maturation. For PCR analyses, genomic DNA was extracted from young leaves according to Doyle and Doyle (1990) and analysed with two primer pairs (forward1 5'-TCTAGAATGGCCACCATTGC-3' and reverse1 5'-GAGCTCTCACTGGCGATGCC-3'; forward2 5'-AATAGCTGCGCCGATGGTTT-3' and reverse2 5'ACCACGGCCTCCAGAAGAAG-3') with the following PCR conditions: one cycle of $5 \mathrm{~min}$ at $95^{\circ} \mathrm{C}, 40$ cycles of $40 \mathrm{~s}$ at $95^{\circ} \mathrm{C}, 40 \mathrm{~s}$ at $58^{\circ} \mathrm{C}$ and $2 \mathrm{~min}$ at $72^{\circ} \mathrm{C}$, followed by a final extension step of $5 \mathrm{~min}$ at $72^{\circ} \mathrm{C}$.

In order to estimate GCase copy number in transgenic rice plants, we used the method of real-time quantitative PCR developed by Ding et al. (2004) in which the rice sucrose phosphate synthase (SPS) gene represents the endogenous reference standard. The oligonucleotide primers and TaqMan probes (Table 2) were designed with the Primer 3 Output software (http://frodo.wi.mit.edu). All probes had the Blackhole Quencher 1 at the 3' end, whereas in $5^{\prime}$ they were labelled with the fluorescent reporter dye Texas Red (SPS-P) or Joe (GCase-P).

RT-PCR was performed with the thermal cycler iCycler $\mathrm{iQ}$ real-time PCR detection system (Bio-Rad) and 1xPlatinum Quantitative PCR SuperMix UDG (Invitrogen). The amplification conditions consisted of one cycle of $3 \mathrm{~min}$ at $50^{\circ} \mathrm{C}$ and $3 \mathrm{~min}$ at $95^{\circ} \mathrm{C}$, followed by 50 cycles of $15 \mathrm{~s}$ at $95^{\circ} \mathrm{C}$ and $1 \mathrm{~min}$ at $60^{\circ} \mathrm{C}$. In order to generate standard curves for DNA quantification, SPS- and GCase-harbouring plasmids were serially diluted and analyzed.

\section{Protein extraction}

Protein extracts for Western blot analyses were prepared as follows: five dehulled seeds were ground with $1 \mathrm{~mL}$ of extraction buffer $(500 \mathrm{mM} \mathrm{NaCl}$ in $50 \mathrm{mM}$ Tris- $\mathrm{HCl}$ buffer, $\mathrm{pH}$ 7.0) using mortar and pestle. The resulting

Table 2 Primer pairs and probes used in real-time quantitative PCR

\begin{tabular}{ll}
\hline Name & Sequence $\mathbf{( 5}^{\prime} \mathbf{3}^{\prime} \mathbf{)}$ \\
\hline SPS for & AACGGATATCTTCAGTTTGTAACCAC \\
SPS rev & CGGTTGATCTTTCGGGATG \\
SPS-P & GATGACGCACGGACGGCTCG \\
GCase for & CCTGCCCTTGGTACCTTCAG \\
GCase rev & GCCCCATACTCAGCTCCATC \\
GCase-P & GAGAGTACACGCAGTGGGCGACG \\
\hline
\end{tabular}

homogenate was incubated at RT for 5 min under agitation and then centrifuged at $15000 \times \mathrm{g}$ for $45 \mathrm{~min}$ at $4^{\circ} \mathrm{C}$. The supernatant $(30 \mu \mathrm{g}$ soluble protein) was directly used for SDS-PAGE.

Protein extracts for ELISA analyses were obtained homogenizing five dehulled seeds with $10 \mathrm{~mL}$ extraction buffer, as above.

To determine rhGCase expression levels, 40 dehulled seeds were milled and thoroughly homogenized in $80 \mathrm{~mL}$ extraction buffer and stirred on ice for $1 \mathrm{~h}$. The extract was centrifuged at $20000 \times \mathrm{g}, 4^{\circ} \mathrm{C}$, for $40 \mathrm{~min}$. The supernatant was collected and stored for DASELISA.

\section{Gel electrophoresis and staining}

SDS-PAGE was performed under standard conditions, using the Mini Protean II apparatus (BioRad), loading the samples in $10 \%$ polyacrylamide gels after denaturation for $5 \mathrm{~min}$. Commercial molecular weight markers (Fermentas) and commercial imiglucerase were used to assess the molecular weight of rhGCase. Gels were stained with EZBlue ${ }^{\mathrm{TM}}$ Gel Staining Reagent (Sigma Aldrich) or with ProteoSilver ${ }^{\mathrm{TM}}$ Silver Stain kit (Sigma Aldrich).

\section{Western blot}

The extracts prepared as above were denaturated under non-reductive conditions and loaded in a $10 \%$ polyacrylamide gel together with Precision Protein Standard (BioRad). The gel was electroblotted to a $0.2 \mu \mathrm{m}$ PVDF membrane (Millipore) with the Trans-blot SD apparatus (BioRad). The blot was blocked with 7.5\% non-fat dry milk (Oxoid) in PBS for $1 \mathrm{~h}$ at RT. After 3 washes with PBS Tween $0.1 \%$, the primary rabbit polyclonal antibody, produced using commercial imiglucerase (Genzyme Corp., Sanofi Aventis) as antigen, was diluted 1:1000 in the blocking buffer and the blot was incubated for $1 \mathrm{~h}$ at RT. Then, the HRP-conjugated secondary antibody (Sigma Aldrich) was diluted 1:10000 and the blot incubated again for $1 \mathrm{~h}$ at RT. After final washes, chemiluminescence was developed with ECL plus (GE Healthcare). To identify the best transgenic lines, samples showing a strong signal were further evaluated by Western blotting using two- or four-fold diluted supernatants.

\section{RhGCase quantification by DAS-ELISA}

A double antibody sandwich ELISA was used to quantify rhGCase in both crude protein extracts and chromatographic fractions. Capture antibody was obtained from the same rabbit antiserum used in Western analyses, purified by affinity chromatography on imiglucerase derivatized resin. Detecting antibody was produced by 
conjugating HRP with capture antibody. Both antibodies were purchased from Davids Biotechnologie (Germany).

SPL maxi binding plates (SPL, Korea) were coated with $2 \mathrm{ng} / \mu \mathrm{L}$ of capture antibody in coating solution (30 mM NaCl, $2.5 \mathrm{mM}$ sodium phosphate buffer, $15 \mathrm{mM}$ sodium azide, $\mathrm{pH} 7.4), 100 \mu \mathrm{L}$ per well. Coating was performed by stirring the plate at $37^{\circ} \mathrm{C}$ for $20 \mathrm{~min}$. Then, the plate was blocked with $3 \%$ BSA solution in PBS with $15 \mathrm{mM}$ sodium azide, at $37^{\circ} \mathrm{C}$ for $20 \mathrm{~min}$, $300 \mu \mathrm{L}$ per well. Crude extracts were diluted 1:30 in dilution buffer (1\% BSA, PBS-Tween $200.1 \%$ solution, $\mathrm{pH} 7.4$ ), added to the plate and incubated at $37^{\circ} \mathrm{C}$ for $20 \mathrm{~min}, 100 \mu \mathrm{L}$ per well. Chromatographic fractions were differently diluted case by case. After three washes with PBS-Tween 20 0.1\%, detecting antibody was applied at $0.8 \mathrm{ng} / \mu \mathrm{L}$ in dilution buffer, $50 \mu \mathrm{L}$ per well at $37^{\circ} \mathrm{C}$ for $20 \mathrm{~min}$. After four washes, detection was performed using TMB Liquid substrate system (Sigma Aldrich), $100 \mu \mathrm{L}$ per well; the reaction was stopped with $1 \mathrm{M}$ $\mathrm{HCl}, 100 \mu \mathrm{L}$ per well. Plates were read with Modulus II microplate reader (Turner Biosystem) at $450 \mathrm{~nm}$.

For rhGCase quantification, a standard curve was built with the following commercial imiglucerase concentrations: $250,125,62.5,31.315 .6,7.8,3.9,2.0 \mathrm{pg} / \mu \mathrm{L}$ in dilution buffer, $100 \mu \mathrm{L}$ per well.

To evaluate rhGCase expression levels in polished seed, serial extracts were diluited 1:100 in ELISA dilution buffer and analyzed separately. The total rhGCase amount was calculated and expressed as $\mathrm{mg}$ per $\mathrm{kg}$ of flour.

\section{Tissue-specific expression analyses}

In order to demonstrate the endosperm-specific expression of rhGCase, Western blot analyses were performed on crude protein extracts obtained from different organs/tissues at the vegetative and reproductive stage. Protein samples were taken from: leaf blade, leaf sheath, stem internode, stem node, root, rachis, glume and husk, unfertilized ovule, immature anther, mature pollen, immature embryo, endosperm, using Tris- $\mathrm{HCl} 50 \mathrm{mM}$, $0.5 \mathrm{M} \mathrm{NaCl}, \mathrm{pH} 7.0$ in mortar and pestle. To extract proteins, the resulting homogenates were incubated on ice for $1 \mathrm{~h}$ under agitation and then centrifuged at $15000 \times \mathrm{g}$ for $45 \mathrm{~min}$ at $4^{\circ} \mathrm{C}$. Protein concentration of the supernatants was determined by a standard Bradford assay (Bradford 1976). Samples (7-15 $\mu \mathrm{g}$ ) were loaded in Laemmli buffer (Laemmli 1970) into a $10 \%$ polyacrylamide gel together with a molecular weight marker (Sigma Aldrich) and a positive control (commercial imiglucerase). At the end of the run, proteins were stained overnight with Coomassie and destained with 20\% methanol and 10\% acetic acid. A second electrophoretic gel was used to blot the proteins onto a PVDF membrane and perform a Western blot analysis as reported in the previous paragraph. SDS-PAGE and Western blotting were performed also on samples extracted from wild type CR W3. Results achieved by Western blotting were eventually confirmed in DAS-ELISA.

\section{Electron and immunoelectron microscopy}

Unlabeled osmium-treated samples were prepared according to Musetti et al. (2011). For immunoelectron microscopy, immature rice seeds (approx. 10-15 days after flowering) were fixed in $0.2 \%$ glutaraldehyde, rinsed in $0.1 \mathrm{M}$ phosphate buffer, $\mathrm{pH} 7.4$, dehydrated in ethanol (25, 50, 75\%, 30 min each step, then $100 \%$ for $1 \mathrm{~h})$, then infiltrated in LR White Resin (LRW, London Resin) with the following ratio: LRW:ethanol 1:2 for $30 \mathrm{~min}$, LRW: ethanol 2:1 for $30 \mathrm{~min}$, and 100\% LRW (two changes: after $1 \mathrm{~h}$, then overnight) at RT. The samples were embedded in fresh LRW resin in BEEM capsules and polymerized at $60^{\circ} \mathrm{C}$ for $24 \mathrm{~h}$.

Ultra-thin sections $(60-70 \mathrm{~nm})$ were cut with the ultramicrotome LKB Nova (Reichter) and mounted on nickel grids (Electron Microscopy Sciences) for immunolocalization. Sections were incubated with Normal Goat Antiserum (Aurion) diluted 1:30 in buffer $C$ (0.05 M Tris- $\mathrm{HCl}, \mathrm{pH} \mathrm{7.6,0.2 \%} \mathrm{BSA)} \mathrm{for} 15 \mathrm{~min}$ and then with the anti-GCase serum diluted 1:500 in buffer $\mathrm{C}$ for $1 \mathrm{~h}$ at RT. After washes, the sections were incubated for $1 \mathrm{~h}$ with a solution of goat anti-rabbit antibody conjugated with $15 \mathrm{~nm}$ colloidal gold (Aurion) diluted 1:40 in $0.02 \mathrm{M}$ Tris- $\mathrm{HCl}, \mathrm{pH} 8.2$, containing $0.9 \% \mathrm{NaCl}$ and $1 \%$ BSA. Sections were stained with $0.1 \%$ lead citrate (Reynolds 1963) and examined with the CM10 transmission electron microscope (Philips).

\section{Seed viability}

One hundred non-vernalized seeds produced by the best transgenic lines were placed onto moistened paper and incubated in petri dishes at $28 / 22^{\circ} \mathrm{C} \mathrm{d} / \mathrm{n}, 16 / 8 \mathrm{~h} \mathrm{~d} / \mathrm{n}$; seeds were daily controlled to determine their viability using untransformed, non-vernalized CR W3 seed as control.

\section{RhGCase purification}

Transgenic rice seed was dehulled, polished with the TO-92 equipment (Satake) and milled in a coffee blender. Rice flour was suspended in cold methanol $(1: 5 \mathrm{w} / \mathrm{v})$, stirred on ice for $5 \mathrm{~min}$ and centrifuged for $15 \mathrm{~min}$ at $14000 \times \mathrm{g}$. After the supernatant was discarded, the pellet was extracted with $2 \mathrm{mM}$ sodium citrate, $\mathrm{pH} 5.5(1: 5 \mathrm{w} / \mathrm{v})$ and centrifuged for $15 \mathrm{~min}$ at $14000 \times \mathrm{g}$; this step was done to eliminate the low-salt soluble protein fraction and for a better efficiency it was repeated twice. At the end of pretreatment, the pellet was extracted with $0.5 \mathrm{M} \mathrm{NaCl}$ in $50 \mathrm{mM}$ Tris- $\mathrm{HCl}$ buffer, $\mathrm{pH} 7.0(1: 5 \mathrm{w} / \mathrm{v})$. The extract was stirred for $5 \mathrm{~min}$ 
at RT and then centrifuged for $15 \mathrm{~min}$ at $14000 \times \mathrm{g}$ to recover the supernatant. In order to extract all the rhGCase protein stored in rice seed, the extraction procedure was repeated three times and the supernatants were pooled and further clarified by centrifugation at $14000 \times \mathrm{g}$ for $45 \mathrm{~min}$ at $4^{\circ} \mathrm{C}$.

RhGCase was purified using a three-step purification process involving HIC (Hydrophobic Interaction Chromatography) for capture, IEC (Ion Exchange Chromatography) for intermediate purification and GF (Gel Filtration) for the polishing step. All chromatographies were performed with the AKTA Prime purification system (GE Healthcare).

For HIC, two 5-mL HiTrap Octyl FF columns (GE Healthcare) were serially connected and equilibrated with one column volume of loading buffer $(10 \mathrm{~mL}$ of $200 \mathrm{mM}$ ammonium sulphate in $50 \mathrm{mM}$ Tris- $\mathrm{HCl}$ buffer, $\mathrm{pH}$ 7.0). A $3 \mathrm{M}$ ammonium sulphate solution was added to the clarified extract to reach a final concentration of $200 \mathrm{mM}$ ammonium sulphate. After filtration with $0.2 \mu \mathrm{m}$ filter (Millipore), $300 \mathrm{~mL}$ of the extract were applied to the column at a $5 \mathrm{~mL} / \mathrm{min}$ flow-rate. The flow-through was reloaded onto the column until three loading volumes were passed. The flow-through was then collected and stored until analysis. The column was washed with $14 \mathrm{col}-$ umn volumes $(140 \mathrm{~mL})$ of $15 \mathrm{mM}$ sodium citrate buffer, $\mathrm{pH}$ 5.5. Elution was carried out by increasing ethylene glycol concentrations from $0 \%$ to $50 \%$ in $15 \mathrm{mM}$ sodium citrate buffer, $\mathrm{pH}$ 5.5. One-mL fractions were collected and tested in ELISA. Positive fractions (from number 3 to number 15) were pooled and loaded in a 1-mL HiTrap SP HR column (GE Healthcare); rhGCase was eluted in 5-mL fractions by a continuous gradient from $60 \mathrm{mM}$ to $200 \mathrm{mM}$ of $\mathrm{NaCl}$ in 20 column volumes $(20 \mathrm{~mL})$.

Gel filtration was used as the final polishing step. A HiPrep 16/60 Sephacryl S-100 High Resolution column (GE Healthcare) was equilibrated with $15 \mathrm{mM}$ sodium citrate and $150 \mathrm{mM} \mathrm{NaCl}, \mathrm{pH}$ 5.5; the column was then loaded with the DAS-ELISA positive IEC fraction (number 3), reduced to $500 \mu \mathrm{L}$ by Amicon Ultra-15 (MWCO $30 \mathrm{kDa}$, Millipore) and run at a flow-rate of $0.5 \mathrm{~mL} / \mathrm{min}$. In order to recognize the rhGCase-containing peak, a preliminary GF was performed with commercial imiglucerase.

\section{Enzymatic assay}

RhGCase activity was assayed using 4-MUG (4methylumbelliferyl $\beta$-D-glucoside, Sigma Aldrich) as substrate. The reaction buffer contained $100 \mathrm{mM}$ sodium acetate buffer, $\mathrm{pH} 5.5,0.5 \% \mathrm{w} / \mathrm{v}$ taurocholate and $10 \mathrm{mM}$ 4-MUG, $50 \mu \mathrm{L}$ per well. The reaction was carried out at $37^{\circ} \mathrm{C}$ for $30 \mathrm{~min}$ and finally stopped with $200 \mu \mathrm{L} 100 \mathrm{mM}$ glycine- $\mathrm{NaOH}, \mathrm{pH}$ 10.0. Fluorescence was read at 410-460 $\mathrm{nm}$ with the fluorimeter Modulus
II microplate reader (UV Optical kit, Turner Biosystem) following excitation at $365 \mathrm{~nm}$. A standard curve was built with 2.5-5.0 nmol 4-MU (4-methylumbelliferone, Sigma Aldrich) in reaction buffer, $200 \mu \mathrm{L}$ per well.

\section{Peptide mass fingerprinting and $\mathrm{N}$-terminal sequencing}

Peptide mass fingerprinting was performed by MALDITOF technology (Perkin Elmer). A purified rhGCase sample was electrophoresed and stained with Coomassie Blue R-250 staining; the band of interest was cut, washed at $37^{\circ} \mathrm{C}$ with a $100 \mathrm{mM} \mathrm{NH} \mathrm{NHCO}_{3}$ and acetonitrile $(\mathrm{ACN})(50: 50 \mathrm{v} / \mathrm{v})$ solution, ground and dehydrated with ACN. The protein was reduced with $10 \mathrm{mM}$ dithiothreitol, alkylated with $50 \mathrm{mM}$ iodoacetamide (IAA) and overnight digested with $50 \mathrm{ng} / \mu \mathrm{L}$ trypsin (Promega) at $37^{\circ} \mathrm{C}$. After a further treatment with $2 \%$ formic acid and $60 \% \mathrm{ACN}$, peptides were purified with a zip-tip C18 (Millipore), removing the contaminants with $0.1 \%$ TFA washes. Peptides were slowly eluted with ACN and 0.1\% TFA (70:50), mixed with a CHCA ( $\alpha-$ cyano-4-hydroxycinnamic acid) matrix and spotted onto a MALDI plate for analysis.

For N-terminal sequencing, a purified rhGCase sample was electrophoresed and blotted onto a PVDF membrane. The rhGCase band was identified by CoomassieBlue staining. The $\mathrm{N}$-terminal sequence was determined by Primm Srl (Milan, Italy) using the Edman degradation method (Edman 1950).

\section{Glycan structure analyses}

Glycosylation patterns were determined using exoglycosidase digestion and MALDI-TOF analyses. In particular, a purified rhGCase sample was run on SDS-PAGE and the band of interest, identified by Coomassie-Blue staining, was cut out and incubated with PNGase F, i.e. peptide-N(4)-(N-acetyl- $\beta$-glucosaminyl) asparagine amidase $F$, to remove the oligosaccharide chains connected to the amidic group of asparagine residues. Oligosaccharide chains were then analysed by MALDI-TOF according to Siemiatkoski et al. (2006).

\section{Abbreviations}

hGCase: human acid-beta-glucosidase; rhGCase: recombinant human acidbeta-glucosidase; GD: gaucher disease; ERT: enzyme replacement therapy; SPS: sucrose phosphate synthase; PSVs: protein storage vacuoles; HIC: hydrophobic interaction chromatography; IEC: ion exchange chromatography; GF: gel filtration; PNGase F: peptide-N(4)-(N-acetyl-beta-Dglucosaminyl)asparagine amidase F; GluB4: glutelin 4; GluB4pro: glutelin 4 promoter; SPGluB4: signal peptide of glutelin 4.

\section{Competing interests}

The authors declare that the technology described in the manuscript was applied for a patent (WO 2009/112508).

\section{Authors' contributions}

TP (principal investigator) carried out gene design, prepared the molecular vectors, performed molecular analyses and contributed to write the paper; ES and CP made the genetic transformation and regeneration of rice plants; 
FM and SV carried out the selection of both primary transformants and their progenies by DAS-ELISA; PC developed DAS-ELISA for quantification of rhGCase and carried its purification; MM took care of plant cultivation and sampling; RC performed MALDI-TOF and glycan analyses; AD carried out uptake assays with human target cells; BB reviewed cellular assays and molecular protein/glycan characterization; RM made electron microscopy; SM conceived the project, participated in molecular genetic studies, provided overall coordination of activities and reviewed internally the paper. All authors read and approved the final manuscript.

\section{Acknowledgements}

We thank Dr. Gian Luca Bianchi and his staff of the biotechnologies laboratory of ERSA Plant Health, Agricultural Chemistry, Analysis and Certification Service (Pozzuolo del Friuli, Udine, Italy) for the real-time quantitative PCR analyses and Dr. Romano Gironi of the Rice Research Centre of Ente Nazionale Risi (Milan, Italy) for the CR W3 rice variety supply.

\section{Author details}

${ }^{1}$ Transactiva Srl, Via J. Linussio 51, 33100 Udine, Italy. ${ }^{2}$ Regional Coordination Centre for Rare Diseases, University Hospital S. Maria Misericordia, P.zale S. Maria della Misericordia 15, 33100 Udine, Italy. ${ }^{3}$ Department of Agriculture and Environmental Sciences, University of Udine, Via delle Scienze 206, 33100 Udine, Italy.

\section{Received: 7 August 2012 Accepted: 27 November 2012}

\section{Published: 6 December 2012}

\section{References}

Aerts JM, Yasothan U, Kirkpatrick P (2010) Velaglucerase alfa. Nat Rev Drug Discov 9:837-838

Arcalis E, Marcel S, Altmann F, Kolarich D, Drakakaki G, Fischer R, Christou P, Stoger $E$ (2004) Unexpected deposition patterns of recombinant proteins in post-endoplasmic reticulum compartments of wheat endosperm. Plant Physiol 136:3457-3466

Aviezer D, Brill-Almon E, Shaaltiel Y, Hashmueli S, Bartfeld D, Mizrachi S, Liberman Y, Freeman A, Zimran A, Galun E (2009) A plant-derived recombinant human glucocerebrosidase enzyme-A preclinical and phase I investigation. PLoS One 4:e4792

Benchabane E, Goulet C, Rivard D, Faye L, Gomord V, Michaud D (2008) Preventing unintended proteolysis in plant protein bioreactors. Plant Biotechnol J 6:633-648

Berg-Fussman A, Grace ME, loannou Y, Grabowski GA (1993) Human acid betaglucosidase. N-glycosylation site occupancy and the effect of glycosylation on enzymatic activity. J Biol Chem 268:14861-14866

Beutler E, Grabowsky GA (2001) Gaucher disease. In: Scriver CR, Beudet A, Sly WS, Valle $D$ (eds) Molecular and metabolic basis of inherited diseases, 8th edn. McGrow-Hill, New York, pp 3635-3656

Bradford MM (1976) A rapid and sensitive method for the quantitation of microgram quantities of protein utilizing the principle of protein-dye binding. Anal Biochem 72:248-254

Brady RO, Kanfer JN, Shapiro D (1965) Metabolism of glucocerebrosides. II. Evidence of an enzymatic deficiency in Gaucher's disease. Biochem Biophys Res Commun 18:221-225

Brumshtein B, Wormald MR, Silman I, Futerman AH, Sussman JL (2006) Structural comparison of differentially glycosylated forms of acid- $\beta$-glucosidase, the defective enzyme in Gaucher disease. Acta Crystallogr D: Biol Crystallogr 62:1458-1465

Chen G, Rothnie HM, He X, Hohn T, Fütterer J (1996) Efficient transcription from the rice tungro bacilliform virus promoter requires elements downstream of the transcription start site. J Virol 70:8411-8421

Cox TM, Schofield JP (1997) Gaucher's disease: clinical features and natural history. In: Gaucher's disease. Baillieres Clin Haematol 10:657-689

Damiano AM, Pastores GM, Ware JE (1998) The health-related quality of life of adults with Gaucher's disease receiving enzyme replacement therapy: results from a retrospective study. Qual Life Res 7:373-386

De Amicis F, Patti T, Marchetti S (2007) Improvement of the pBl121 plant expression vector by leader replacement with a sequence combining a poly (CAA) and a CT motif. Transgenic Res 16:731-738

Ding J, Jia J, Yang L, Wen H, Zhang C, Liu W, Zhang D (2004) Validation of a rice specific gene, sucrose phosphate synthase, used as the endogenous reference gene for qualitative and real-time quantitative PCR detection of transgenes. J Agric Food Chem 52:3372-3377

Doran PM (2006) Foreign protein degradation and instability in plants and plant tissue cultures. Trends Biotechnol 24:426-432

Doyle JJ, Doyle JL (1990) Isolation of plant DNA from fresh tissue. Focus 12:13-15

Edman P (1950) Method for the determination of the amino acid sequence in peptides. Acta Chem Scand 4:283-293

Emanuelsson O, Brunak S, von Heijne G, Nielsen H (2007) Locating proteins in the cell using TargetP, SignalP and related tools. Nat Protoc 2(4):953-971

Fischer R, Schillberg S, Hellwig S, Twyman RM, Drossard J (2012) GMP issues for recombinant plant-derived pharmaceutical proteins. Biotechnol Adv 30:434-439

Futerman AH, Sussman JL, Horowitz M, Silman I, Zimran A (2004) New directions in the treatment of Gaucher disease. Trends Pharmacol Sci 25:147-151

Grabowski GA, Barton NW, Pastores G, Dambrosia JM, Banerjee TK, McKee MA, Parker C, Schiffmann R, Hill SC, Brady RO (1995) Enzyme therapy in Type 1 Gaucher disease: comparative efficacy of mannose-terminated glucocerebrosidase from natural and recombinant sources. Ann Intern Med 122:33-39

Hiei Y, Ohta S, Komari T, Kumashiro T (1994) Efficient transformation of rice (Oryza sativa L.) mediated by Agrobacterium and sequence analysis of the boundaries of the T-DNA. Plant J 6:271-282

Hollak CE, Vom Dahl S, Aerts JM, Belmatoug N, Bembi B, Cohen Y, Collin-Histed T, Deegan P, van Dussen L, Giraldo P, Mengel E, Michelakakis H, Manuel J, Hrebicek M, Parini R, Reinke J, Di Rocco M, Pocovi M, Sa Miranda MC, TylkiSzymanska A, Zimran A, Cox TM (2009) Force majeure: therapeutic measures in response to restricted supply of imiglucerase (Cerezyme) for patients with Gaucher disease. Blood Cells Mol Dis. doi:10.1016/j.bcmd.2009.09.006

Humphrey BD, Huang N, Klasing KC (2002) Rice expressing lactoferrin and lysozyme has antibiotic-like properties when fed to chicks. J Nutr 132:1214-1218

Kawakatsu T, Yamamoto MP, Hirose1 S, Yano M, Takaiwa F (2008) Characterization of a new rice glutelin gene GluD-1 expressed in the starchy endosperm. J Exp Bot 59(15):4233-4245

Laemmli UK (1970) Cleavage of structural proteins during the assembly of the head of bacteriophage T4. Nature 227:680-685

Lerouge P, Cabanes-Macheteau M, Rayon C, Fischette-Laine AC, Gomord V, Faye $L$ (1998) N-glycoprotein biosynthesis in plants: recent developments and future trends. Plant Mol Biol 38:31-48

Meikle PJ, Hopwood JJ, Clague AE, Carey WF (1999) Prevalence of lysosomal storage disorders. JAMA 282:249-254

Musetti R, Grisan S, Polizzotto R, Martini M, Paduano C, Osler R (2011) Interactions between 'Candidatus Phytoplasma mali' and the apple endophyte Epicoccum nigrum in Catharanthus roseus plants. J Appl Microbiol 110(3):746-756

Qu LQ, Takaiwa F (2004) Evaluation of tissue specificity and expression strenght of rice seed component gene promoters in transgenic rice. Plant Biotechnol J 2:113-125

Reggi S, Marchetti S, Patti T, De Amicis F, Cariati R, Bembi B, Fogher C (2005) Recombinant human acid $\beta$-glucosidase stored in tobacco seeds is stable, active and taken up by human fibroblasts. Plant Molec Biol 57:101-113

Reynolds ES (1963) The use of lead citrate at high pH as an electron-opaque stain in electron microscopy. J Cell Biol 17:208-212

Schillberg S, Fischer R, Emans N (2003) Molecular farming of recombinant antibodies in plants. Cell Mol Life Sci 60:433-445

Shaaltiel Y, Barfeld D, Hashmueli S, Baum G, Brill-Almon E, Galili G, Dym O, BoldinAdamsky SA, Silman I, Sussman JL, Futerman AH, Aviezer D (2007) Production of glucocerebrosidase with terminal mannose glycans for enzyme replacement therapy of Gaucher's disease using a plant cell system. Plant Biotechnol J 5:579-590

Siemiatkoski J, Lyubarskaya Y, Houde D, Houde D, Tep S, Mhatre R (2006) A comparison of three techniques for quantitative carbohydrate analysis used in characterization of therapeutic antibodies. Carbohydr Res 341:410-419

Takaiwa F, Ogawa M, Okita TW (1999) Rice glutelins. In: Shewry P, Casey R (eds) Seed proteins. Kluwer Academic Publishers, Dordrecht, FL, pp 401-426

Takaiwa F, Takagi H, Hirose S, Wakasa Y (2007) Endosperm tissue is good production platform for artificial recombinant proteins in transgenic rice. Plant Biotechnol J 5:84-92

Twyman RM, Stoger E, Schillberg S, Christou P, Fischer R (2003) Molecular pharming in plants: host system and expression technology. Trends Biotechnol 21:570-578 
Vitale A, Pedrazzini E (2005) Recombinant pharmaceuticals from plants: the plant endomembrane system as bioreactor. Mol Interv 5:216-225

Yan X, Gonzales RA, Wagner GJ (1997) Gene fusions of signal sequences with a modified $\beta$-glucuronidase gene results in retention of the $\beta$-glucuronidase protein in the secretory pathway/plasma membrane. Plant Physiol 115:915-924

doi:10.1186/1939-8433-5-34

Cite this article as: Patti et al.: Endosperm-specific expression of human acid beta-glucosidase in a waxy rice. Rice 2012 5:34.

Submit your manuscript to a SpringerOpen ${ }^{\circ}$ journal and benefit from:

- Convenient online submission

- Rigorous peer review

- Immediate publication on acceptance

- Open access: articles freely available online

- High visibility within the field

- Retaining the copyright to your article

Submit your next manuscript at $\boldsymbol{\nabla}$ springeropen.com 